\title{
CORPORATE SOCIAL RESPONSIBILITY DISCLOSURE, INVESTMENT EFFICIENCY, INNOVATION, AND FIRM VALUE
}

\author{
Dien Ajeng Fauziah ${ }^{1}$ \\ University of Brawijaya \\ Veteran St., Malang \\ Indonesia 65145 \\ dien.ajeng.fauziah@gmail.com*
}

\author{
Eko Ganis Sukoharsono ${ }^{2}$ \\ University of Brawijaya \\ Veteran St., Malang \\ Indonesia 65145 \\ ekoganis@yahoo.com
}

\author{
Erwin Saraswati ${ }^{3}$ \\ University of Brawijaya \\ Veteran St., Malang \\ Indonesia 65145 \\ erwin_saraswati@yahoo.com
}

\begin{abstract}
This research purpose is to analyze the effect of Corporate Social Responsibility Disclosure on the value of environmentally risky companies, as those in agricultural, primary industry and chemicals, mining, property, real estate, and building construction sectors, listed on the IDX from 2015 to 2018 through investment efficiency and innovation. The results of the PLS analysis indicate that such disclosure positively and insignificantly affects firm value through investment efficiency. Better exposure and efficiency tend to increase substantial value, although the improvement is insignificant in the underinvestment scenario. Furthermore, the disclosure positively and significantly enhances firm value through innovations with research and development activities.
\end{abstract}

Keywords: $\quad$ CSRD; Investment Efficiency; Innovation; Firm Value

\begin{abstract}
ABSTRAK
Penelitian bertujuan untuk menguji dan menganalisis pengaruh CSRD terhadap nilai perusahaan melalui efisiensi investasi dan inovasi pada perusahaan berisiko dalam hal dampak lingkungan seperti sektor Agriculture, Basic Industry dan Chemicals, Mining, Property, Real Estate dan Building Construction terdaftar di BEI tahun 2015-2018. Penelitian ini menggunakan metode PLS sebagai analisis data. Hasil penelitian menunjukkan bahwa CSRD berpengaruh positif dan tidak signifikan terhadap nilai perusahaan melalui efisiensi investasi, artinya semakin baik CSRD dan efisiensi investasi maka cenderung dapat meningkatkan nilai perusahaan, meskipun peningkatannya tidak signifikan pada skenario underinvestment dan CSRD berpengaruh positif dan signifikan terhadap nilai perusahaan melalui inovasi dengan aktivitas $R n D$.
\end{abstract}

Kata Kunci : $\quad$ CSRD; Efisiensi Investasi; Inovasi; Nilai Perusahaan JEL Classification: M410; G340

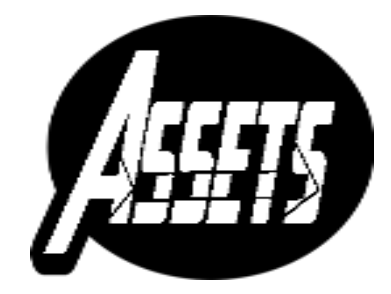

ASSETS

Jurnal Akuntansi dan Pendidikan

Vol. 10 No. 1

Page 11 - 22

Madiun, April 2021 p-ISSN: 2302-6251 e-ISSN: 2477-4995

Article History

Submitted:

April 6, 2020

Accepted:

April 22, 2021 


\section{INTRODUCTION}

Firm value is essential for companies since it determines their business strength and sustainability (Orbaningsih et al., 2017). Stock price reflects investor's expectations about the company's profit. The higher the gain, the higher the possibility of the company's stock to increase, leading to higher firm value. Siswanti et al. (2015), who measured firm value over price-to-book value (PBV), found that companies with high firm values are those whose PBV is above one. According to the release on the IDX website (www.idx.co.id), 2018 is the worst year in terms of the composite index (IHSG) in the past three years, negative $2.54 \%$. The return was still $19.99 \%$ in 2017 and $15.32 \%$ in 2016. In the last four years, the composite index had the highest return of $19.99 \%$ in 2017 when it closed at 6,355,65. The recovery was $15.32 \%$ in 2016 when closed at 5,296.71. During the 2015-2018, the PBV of coal mining companies has fluctuated due to companies' internal and external factors (Kusumah, 2018), either the stock price, amount of equity, or listed shares (Amrulloh, 2019).

This research aims to examine and analyze the effect of corporate social responsibility disclosure (CSRD) on firm value through investment efficiency and innovation. The study of Cook et al. (2019) confirms the stakeholder theory, which was proven by the influence of CSR disclosure on investment efficiency and innovation, which is explicitly based on the view of an organization and its environment (M. Nur \& Priantinah, 2012). CSR disclosure can enhance the company's legitimacy, which can provide positive values in trust and legitimacy from the community to the company (Adhiwardana \& Daljono, 2013). According to signal theory, giving positive signals in the forms of information related to CSR is expected to reduce information asymmetry between management and stakeholders and increase stakeholder's trust and legitimacy in the company. The company's reputation or image increases, and public interest to invest in the company through shares also gains. Eventually, the company's stock prices and value also increase (Rustiarini, 2010).

There are several studies on the effect of CSR disclosure on firm value; the results vary. Deng et al. (2013), Harjoto \& Laksmana (2018), Li et al. (2018), Meilinda Murnita \& Dwiana Putra (2018), Cho et al. (2019), and Nur et al. (2019) found that there is a significant relationship between CSR and firm value. On the other hand, the studies of Stacia \& Juniarti (2015), Dian \& Lidyah (2016), Hafez (2016), Chen \& Lee (2017), Deswanto \& Siregar (2018), Sheikh (2018), and Kholida \& Susilo (2019) found that the application of CSR disclosure does not affect firm value.

Previous researchers have found that CSR plays a vital role in promoting investment efficiency (Bhandari \& Javakhadze, 2017; Benlemlih \& Bitar, 2018; Cook et al., 2019). Samet \& Jarboui (2017) argued that CSR performance is an effective mechanism that can reduce asymmetric information and cash flow problems and increase investment at the company level. CSR-driven innovation is about "doing the right things," while innovation-driven CSR is about "doing things right" (MacGregor \& Fontrodona, 2011). According to Sukoharsono (2019), sustainability reporting does exist a new framework from the Triple Bottom Line to Pentaple Bottom Line, namely People, Profit, Planet, Phenotechnology, and Prophet. Phenotechnology is the fact that the existence or phenomenon of information technology must be an essential part of an organization's survival. Disclosures about phenotechnology may include implementations of software, hardware, networks, telecommunications, and databases. Corporate innovation can be defined as phenotechnology for the quality and quantity of CSR disclosure and reporting.

This research contributes to the company as the business actor in resolving asymmetric information problems through the provision of signals to external parties.

http://doi.org/10.25273/jap.v10i1.6259 
The use of CSR in improving corporate image through asymmetric information reduction requires rules or standards on the brink of technological dimension 4.0. The novelty of this study is the use of investment efficiency and innovation variables as mediators for the effect of CSRD on firm value. Investment efficiency is used to reduce information asymmetry, as well as to provide signals to investors, and create innovation for $\mathrm{RnD}$ activities and expenditures so that companies can apply sustainability-oriented innovation Klewitz \& Hansen (2014) and green innovation or eco-innovation (Weng et al., 2015).

\section{METHOD}

This study uses explanatory research, explaining the causal relationship between variables and Partial Least Squares (PLS) analysis. The population of this study is all companies listed on the Indonesia Stock Exchange from 2015 to 2018, especially the category-1 companies in the industrial group, such as agriculture, primary industry and chemicals, mining, property, real estate, and building construction. It is chosen because the companies are high risk in their operations and high impact on the environment, as published on the official websites of IDX and the company (Muqodim \& Susilo, 2013).

This quantitative research uses secondary data obtained from the companies' annual reports and sustainability reports. The data was harvested through the documentation by collecting all secondary data and required information; then also used content analysis. The database method was used to collect data from various sources such as journals, previous researches, and other written data sources related to the study. The content analysis method analyzes CSR disclosure through corporate social responsibility reports and annual reports.

\section{Table 1. Criteria of Sample Companies}

\begin{tabular}{lr}
\hline Criteria & Number \\
\hline Companies listed on the IDX during the 2015-2018 period & 2596 \\
Companies not included in group 1 & 1708 \\
Companies inconsistently listed during the 2015-2018 period & 180 \\
Companies using foreign currencies in their annual reports & 176 \\
Companies inconsistently publish annual reports during the 2015-2018 period & 28 \\
Total sample & 504 \\
\hline
\end{tabular}

Table 1. shows sample companies' parameters focused on deliberate screening of various criteria. In 2015-2018, there was a total population of 2596 companies listed on the IDX. Companies that were not included in category 1, as mentioned by Muqodim \& Susilo (2013), such as farmers, the primary industry and chemicals, mining, and land, real estate and building, pose a high risk in their activities and having a high environmental impact of a total of 1.180 enterprises. They were reported inconsistently on the IDX in 2015. One hundred seventy-six enterprises were using annual reports rather than IDR. It prevents distortion in calculating factors resulting from currency fluctuations. Moreover, in the release of the 2015-2018 yearly study, some 28 businesses were deleted from survey requirements by incoherence. Therefore, 504 observations were received in total.

Any variable studied in this analysis and how to calculate it is defined in Table 2. This analysis included four variables; one independent variable, CSRD (Muqodim \&

This work is licensed under a Creative Commons Attribution-ShareAlike 4.0 International License. 
Susilo, 2013), two mediator variables, investment efficiency (García Lara et al., 2016) and innovation (Prihadyanti \& Laksani, 2015), and one dependent variable, firm value (Willim, 2015).

Table 2. Operational Variable

\begin{tabular}{|c|c|c|}
\hline Variable & Definition & Measurement \\
\hline CSRD & $\begin{array}{l}\text { CSR disclosure based on quantity and } \\
\text { quality }\end{array}$ & $\begin{array}{l}\text { (Muqodim \& Susilo, 2013) } \\
\text { Disclosure Quantity of "How } \\
\text { Many" } \\
\text { Disclosure Quality of "How It is } \\
\text { Measured" }\end{array}$ \\
\hline EffInvest & $\begin{array}{l}\text { Investment efficiency, which is when a } \\
\text { company invests in projects with } \\
\text { positive values (positive NPV) and } \\
\text { under the scenario that there is no } \\
\text { adverse selection (information } \\
\text { asymmetry) }\end{array}$ & $\begin{array}{l}\text { (García Lara et al., 2016) } \\
\text { INVEST i,t+1 }=\beta 0+\beta 1 \text { Sales } \\
\text { Growth } i, t+\varepsilon_{i, t+1}\end{array}$ \\
\hline XRD & $\begin{array}{l}\text { Company information if it reports } \\
\text { research and development cost based } \\
\text { on the category of RnD expenses }\end{array}$ & $\begin{array}{l}\text { (Prihadyanti \& Laksani, 2015) } \\
\text { Variable with the code category } \\
\text { of (1) no expenses, (2) less than } \\
0.5 \% \text {, (3) between } 0.5-0.99 \% \text {, and } \\
\text { (4) } 1 \% \text { or more }\end{array}$ \\
\hline $\begin{array}{l}\text { Tobin's } \\
Q\end{array}$ & $\begin{array}{l}\text { The ratio between the company assets' } \\
\text { market value that is measured by the } \\
\text { market value of the number of stocks } \\
\text { outstanding and debts (enterprise } \\
\text { value) and the replacement cost of the } \\
\text { company's assets }\end{array}$ & $\begin{array}{l}\text { (Willim, 2015) } \\
\mathrm{Q}=\frac{\text { Market Value Shares + Debt }}{\text { Total Assets }}\end{array}$ \\
\hline
\end{tabular}

\section{RESULT AND DISCUSSION}

Table 3. Descriptive Analysis explains that Corporate Social Responsibility Disclosure (CSRD) in this research was measured using content analysis on "how many" disclosure quantity and "how it is measured" disclosure quality (Muqodim \& Susilo, 2013). The results of the descriptive analysis inform that the CSRD of group 1 companies listed on the IDX from 2015 to 2018. The lowest score is for Metro Realty Tbk. (MTSM). The score of this property, real estate dan construction company in 2015 is 0.0000 because it did not give any statement concerning its CSR activities. The smaller standard deviation value than the average value, i.e., $0.3826<0.7572$, indicates that the data deviation and the CSRD score variation of the sample companies are relatively low.

Table 3. Descriptive Analysis

\begin{tabular}{lcccc}
\hline Variable & Minimum & Maximum & Mean & Standard Deviation \\
\hline CSRD & 0.0000 & 1.8393 & 0.7572 & 0.3826 \\
Investment & & & & \\
efficiency & -0.9925 & -0.0002 & -0.0469 & 0.0916 \\
Innovation & 1.0000 & 4.0000 & 1.1468 & 0.4907 \\
Firm Value & 0.1228 & 7.9797 & 1.3090 & 1.0373 \\
\hline
\end{tabular}


Investment efficiency (EI) in this research was measured from the model's residual value (García Lara et al., 2016). The negative residual indicates underinvestment in that the investment expenses made by a company are lower than the expectation. The company with the lowest investment efficiency is Capitalinc Investment Tbk. (MTFN), a mining company whose score was -0.9925 point in 2016. The company with the highest investment efficiency is Fajar Surya Wisesa Tbk. (FASW), a basic industry dan chemicals company, whose score was -0.0002 point in 2017. The mean of -0.0469 and deviation standard of 0.0916 indicates that most companies under study tend to be inefficient, and the data deviation and investment efficiency score variation are relatively high.

Innovation (IN) in this study was measured based on the four categorizations of RnD expenses-to-sales ratio (XRD) (Prihadyanti \& Laksani, 2015). The lowest innovation is 1.0000 , categorized as 1 , which means no expenses. The highest creation is 4.0000 , classified as 4 , which means XRD 1\% or more. Companies with the highest score, from 2015 to 2018, are Lion Metal Works Tbk. (LION) and Champion Pacific Indonesia Tbk. (IGAR), primary industry and chemicals companies. The mean value of innovation of 1.1468 indicates that many sample companies do not spend any for, or do not report, any for XRD cost. The higher means than the standard deviation of 0.4907 show the innovation of group 1 industry companies listed in the IDX from 2015 to 2018. The data deviation and innovation score variation of the sample companies are relatively low.

In this study, firm value (NP) is proxied by Tobin's Q (Willim, 2015). The lowest firm value is 0.1228 , which belongs to Indonesia Prima Property Tbk. (OMRE), a property, real estate, and building construction company in 2016. The lowest firm value is 7.9797, which belongs to Pelat Timah Nusantara Tbk. (NIKL), a primary industry and chemicals company, in 2017. The minor standard deviation score than the mean value, i.e., $1.0373<1.3090$, indicates that the sample companies' data deviation and firm value score variation are relatively low.

\section{Partial Least Squares (PLS) Analysis}

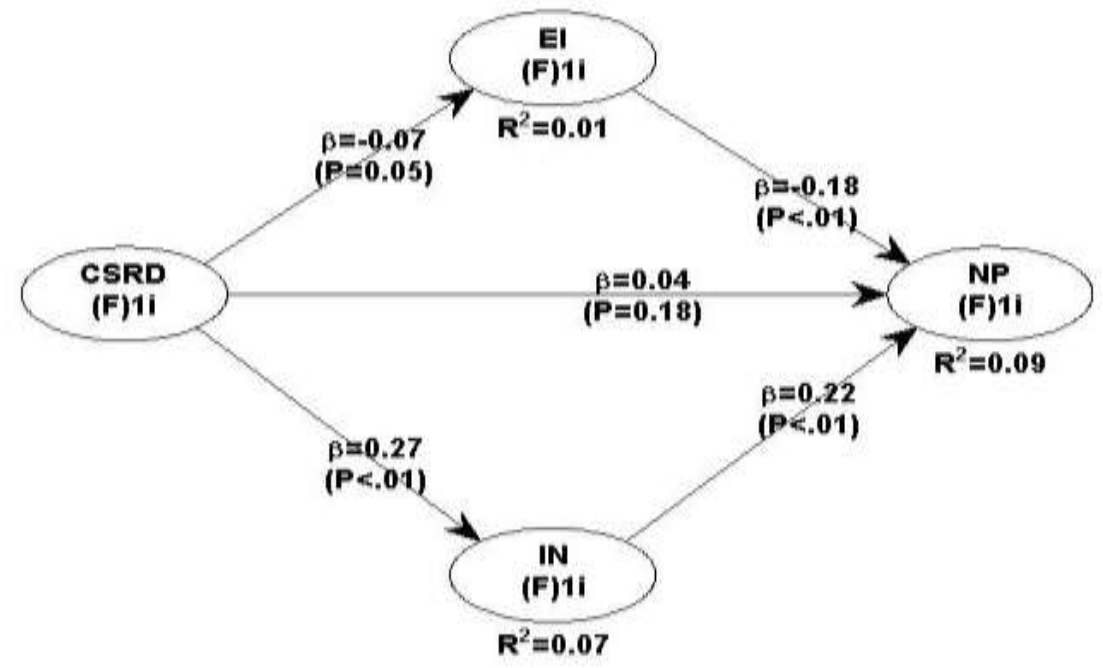

Figure 1. Path Diagram

Table 4. Convergent Validity with Formative Model, the analysis results indicate that all indicators measuring CSRD, investment efficiency, innovation, and firm value 
have the p-value < level of significant (5\%). Hence, the indicators are valid because they can measure CSRD, investment efficiency, innovation, and firm value.

Table 4. Convergent Validity with Formative Model

\begin{tabular}{lcccc}
\hline \multicolumn{1}{c}{ Variable } & Weight & SE & P-value & Notes \\
\hline CSRD & 1.000 & 0.039 & $<0.001$ & Valid \\
Investment Efficiency & 1.000 & 0.039 & $<0.001$ & Valid \\
Innovation & 1.000 & 0.039 & $<0.001$ & Valid \\
Firm Value & 1.000 & 0.039 & $<0.001$ & Valid \\
\hline
\end{tabular}

Table 5, the R-Squared score of investment efficiency is 0.005 (0.5\%), showing that CSRD explains the variation of investment efficiency at $0.5 \%$. In other words, the contribution of CSRD to investment efficiency is $0.5 \%$. The remaining $99.5 \%$ is the contribution of different variables not included in this study. The Q-squared of investment efficiency is 0.006, indicating that CSRD has a fragile predictive strength toward investment efficiency.

Table 5. The goodness of Fit Model

\begin{tabular}{lcc}
\hline Endogenous Variable & R-Squared & Q-Squared \\
\hline Investment Efficiency & 0.005 & 0.006 \\
Innovation & 0.074 & 0.084 \\
Firm Value & 0.088 & 0.090 \\
\hline
\end{tabular}

The R-Squared score of innovation is 0.074 (7.4\%), showing that CSRD explains the variation of creation at $7.4 \%$. In other words, the contribution of CSRD to innovation is $7.4 \%$. The remaining $92.6 \%$ is the contribution of different variables not included in this study. The Q-squared of the invention is 0.084 , indicating that CSRD has a weak predictive strength toward innovation.

The R-Squared score of firm value is $0.088(8.8 \%)$, showing that CSRD explains the variation at $8.8 \%$. In other words, the contribution of CSRD to firm value is $8.8 \%$. The remaining $91.2 \%$ is the contribution of different variables not included in this study. The Q-squared of substantial importance is 0.090, indicating that CSRD, investment efficiency, and innovation have a weak predictive strength toward firm value.

Table 6. Conversion of Path Diagram into Structural Model

\begin{tabular}{|c|c|c|c|c|}
\hline Exogenous & Intervening & Endogenous & $\begin{array}{c}\text { Direct } \\
\text { Coefficient }\end{array}$ & $\begin{array}{c}\text { Indirect } \\
\text { Coefficient }\end{array}$ \\
\hline & & Investment & & \\
\hline & & Efficiency & -0.071 & \\
\hline & & Innovation & $0.273^{*}$ & \\
\hline CSRD & & Firm Value & 0.040 & \\
\hline Investment Efficiency & & Firm Value & $-0.182^{*}$ & \\
\hline Innovation & & Firm Value & $0.217^{*}$ & \\
\hline CSRD & Investment Efficiency & Firm Value & & 0.013 \\
\hline CSRD & Innovation & Firm Value & & $0.059^{*}$ \\
\hline
\end{tabular}

Notes: * (Significant (alpha $(\alpha)=0.05))$ 
Table 6. Conversion of Path Diagram into Structural Model describes the direct effect and indirect effect coefficient on each variable and the correlations between the variables.

\section{Corporate Social Responsibility Disclosure and Firm Value}

This study finds that CSRD has a positive and insignificant effect on firm value. It means that better CSRD tends to increase firm value, although the improvement is not significant. The finding that CSRD does not influence substantial value confirms the study of Stacia \& Juniarti (2015), Dian \& Lidyah (2016), Hafez (2016), Chen \& Lee (2017), Deswanto \& Siregar (2018), Sheikh (2018), and Kholida \& Susilo (2019). On the contrary, the result of this research is not consistent with the findings of previous studies by Deng et al. (2013), Harjoto \& Laksmana (2018), Li et al. (2018), Meilinda Murnita \& Dwiana Putra (2018), Cho et al. (2019), and Nur et al. (2019) in that CSR disclosure positively influences firm value.

The finding does not provide any empirical support that companies that have conducted CSR and disclosed their social responsibility information comprehensively will have higher firm values. The low CSR disclosure quality and conformance to GRI's standard are factors that make CSR practices do not influence firm value (Fajriana \& Priantinah, 2016). It is caused by several phenomena such as the tendency of investors to buy stocks, low CSR disclosure, and the impossibility of CSR to be measured directly (Pristianingrum, 2017). Laws about limited companies number 40 of 2007 on CSR implementation CSR (Kholida \& Susilo, 2019) make sample companies in the property. Real estate dan building construction does not have to disclose their CSR since the reporting is voluntary. According to government regulation number 23 of 2010 on the operation of mineral and coal business, CSR disclosure and reporting are mandatory for companies in agriculture, primary industry dan chemicals, and mining.

Based on this, the findings of this study support the legitimacy theory and signals, namely that the greater the CSR, which is a positive signal conveyed by the firm, may have an impact on investor sentiment. Investors may decide to invest based on a company's indications, thereby increasing the company's valuation. The stronger the signal the firm sends, the more confident people will make investments that then affect the company's valuation. The findings of this study show that scientific evidence for the high importance of an organization for companies involved in the implementation and reporting of more transparent and broad knowledge on social responsibility.

\section{Corporate Social Responsibility Disclosure, Investment Efficiency, and Firm Value}

This research finds that CSRD through investment efficiency positively and insignificantly influences firm value. It means that better investment efficiency caused by better CSRD tends to increase substantial value, although the improvement is insignificant. The negative residual on investment efficiency shows that the real investment is lower than the expected investment level, representing the underinvestment scenario (Benlemlih \& Bitar, 2018). This finding confirms the result of Khanghah \& Zeynali (2017) that companies' CSR positively influences investment efficiency. It also negatively affects overinvestment and capital deficiency in underinvestment scenarios. The relationship between CSR disclosure and investment efficiency shows that the relationship is insignificant for underinvesting companies. It is related to the use of additional resources in CSR activities required by companies' 
non-stakeholders; as a consequence of CSR disclosure, companies have to provide essential public information about their CSR activities (Hung et al., 2013).

Based on the above, the finding of this research does not support stakeholder and signal theories. CSR investment cannot be considered an effective way to improve investment efficiency. CSR components that do not directly relate to main stakeholders do not benefit the company. Increasing community activities and proper human practices help companies improve their reputation as socially responsible companies. Still, such actions are not quite attractive for investment efficiency and do not influence investment decisions. It also fails to increase investment efficiency, particularly during financial stability, which can increase firm value.

The findings suggest that investment productivity cannot fully mediate the relationship between CSRD and firm valuation. More broadly, this research adds to our knowledge of the importance of financial disclosures in emerging markets. Corporate investment performance is critical for economic growth, but significant intelligence asymmetry and organization disputes exist between insiders and foreign investors. Both the investment community and decision-makers should benefit from a better understanding of the variables that affect investment performance in these markets.

\section{Corporate Social Responsibility Disclosure, Innovation, and Firm Value}

This study also finds that CSRD through innovation positively and significantly increases firm value. It means that better innovation caused by better CSRD tends to enhance substantial value. Innovation also seems to have the most significant effect on or to be the most influential for firm value, implying the importance of making R\&D activities and reporting the cost. This finding is relevant with the results of Rexhepi et al. (2013), Handayani et al. (2017), and Mishra (2017), which shows the correlation between R\&D and CSR considering that companies must apply corporate social responsibility principles on the product, process, and productive practice that require changes in technology. Some companies have reported their research and development activities in agriculture, primary industry and chemicals, and mining sectors. In contrast, companies in Property, Real Estate, and Building Construction have not reported their R\&D activities, although their environmental impact is very high.

Based on the explanation above, it can be concluded that this study supports stakeholder and signal theories. Companies that are committed to CSR explicitly pay attention to various stakeholders in their strategy. Better CSR performance focuses on long-term goals and complies with more considerable supervision by many stakeholders. The support of its stakeholders influences the existence of a company. The more powerful the stakeholder, the more the company's effort to adapt. Firm value increases along with innovation intensity in companies with strong CSR. Companies can apply sustainability-oriented innovation concepts (Klewitz \& Hansen, 2014) and green innovation or eco-innovation (Weng et al., 2015) in developing products and processes that contribute to sustainable development and apply commercial knowledge direct and indirect ecological improvements. It covers a series of related ideas from the advancement of environmentally friendly technology and innovative ways that are socially acceptable toward sustainability.

The findings suggest that creativity will fully mediate the relationship between CSRD and firm value. The results indicate that CSRD has a significant positive impact on innovation in line with the MacGregor \& Fontrodona (2011) study, which means that CSR-driven innovation is about "doing the right things," so engaging in the quality and quantity of CSR transparency will implicitly promote the growth of new company 
products and processes. Innovative organizational practices will stimulate optimistic signal interest on the part of customers to invest in the business so that the firm's value can be optimally attained.

This research contributes to understanding the economic impact of CSR disclosure and has important implications for regulators, companies, and investors. The results serve as arguments that can be used by supervisory bodies to enforce CSR disclosure. Companies and investors must consider the effect of CSR disclosure on information asymmetry and the impact on capital availability and cost. Effective CSR requires comprehension of the social dimensions of competitive corporate context that influences companies' capability to improve productivity and carry out strategies (Marin et al., 2017). The effect of CSR disclosure is a double-bladed sword in the underinvestment scenario. On the one side, it generates additional income from external parties; on the other side, the additional capital makes non-stakeholders ask for different CSR (Zhong \& Gao, 2017). In an underinvestment scenario, when information asymmetry resolution related to CSR disclosure moves investment to a higher level, additional expenses can move investment level to the opposite direction, balancing the early increase in investment efficiency. Furthermore, CSR can create stockholder value for several industries with some companies and specific managerial strategies, particularly in innovation, regarding the role of innovation and investment in the relationship between CSR and competitiveness (Gallego-Álvarez et al., 2011).

\section{CONCLUSION}

This study aims to empirically assess and prove the effect of CSRD on firm value through investment efficiency and innovation. This study finds that CSRD positively and insignificantly influences firm value. CSRD positively and insignificantly affects a firm's value through investment efficiency in the underinvestment scenario. CSRD positively and significantly influences a firm's value through innovation. In the case of $R \& D$ activities reported using R\&D expenses, innovation has the dominant effect on firm value. CSR disclosure is made to gain positive assessment and legitimacy from the public. The CSR performance of companies that invest more in R\&D leads to investor's positive evaluation in the capital market and market value increase. According to signal theory, management takes actions by informing investors about how the management sees the company's future. The effect of investment efficiency and innovation on firm value is based on signal theory. The theory highlights the importance of the information provided by companies for external parties' investment decisions. Information published as announcements will give signals to investors in investment decision-making. Companies can consider publishing their sustainability report apart from their annual report to become more transparent and enhance the company's reputation in front of the public and attract more investments. Stakeholder theory assumes that companies' existence depends on stakeholders. In this case, social disclosure must be recognized as the dialogue between management and stakeholders.

The analysis of the quantity and quality of CSR disclosure using content analysis can be very subjective if one primary researcher does it. Therefore, the study should involve research partners or assistants for a more objective CSRD assessment. The research should be conducted in 10 years to keep up with the research trend. It is advised that consequent studies in this field observe the improvement of stakeholders' relationships, capital cost, enhancement of access to capital, and income persistence. There may be a mediating effect of investment efficiency between CSRD and firm value. Future researchers can investigate the relationship between CSRD and efficient

This work is licensed under a Creative Commons Attribution-ShareAlike 4.0 International License. 
investment in financial service and manufacturing sectors or international contexts. This study can also be expanded by taking the perspective of innovation, either sustainability-oriented innovation, green innovation, or eco-innovation, to identify the mediating effect of CSR disclosure on firm value or the impact of CSR on company competitiveness.

\section{REFERENCES}

Adhiwardana, E., \& Daljono, D. (2013). Pengaruh Corporate Social Responsibility dan Kepemilikan Asing Terhadap Kinerja Perusahaan (Studi Empiris pada Perusahaan Manufaktur yang Terdaftar di Bursa Efek Indonesia). Diponegoro Journal of Accounting, 2(2), 1-12.

Amrulloh, M. F. (2019). Pengaruh Kebijakan Deviden, Kebijakan Hutang, Kebijakan Investasi Dan Profitabilitas Terhadap Nilai Perusahaan Pada Perusahaan Manufaktur Yang Terdaftar Di Bursa Efek Indonesia Periode 2015-2017. Journal of Chemical Information and Modeling, 53(9), 1689-1699.

Anggraeni, D. Y., \& Djakman, C. D. (2018). Pengujian Terhadap Kualitas Pengungkapan CSR Di Indonesia. EKUITAS (Jurnal Ekonomi Dan Keuangan), 2(1), 22-41.

Benlemlih, M., \& Bitar, M. (2018). Corporate Social Responsibility and Investment Efficiency. Journal of Business Ethics, 148, 647-671.

Bhandari, A., \& Javakhadze, D. (2017). Corporate social responsibility and capital allocation efficiency. Journal of Corporate Finance, 43, 354-377.

Chen, R. C. Y., \& Lee, C. H. (2017). The influence of CSR on firm value: an application of panel smooth transition regression on Taiwan. Applied Economics, 49(34), 3422-3434.

Cho, S. J., Chung, C. Y., \& Young, J. (2019). Study on the relationship between CSR and financial performance. Sustainability (Switzerland), 11, 343.

Cook, K. A., Romi, A. M., Sánchez, D., \& Sánchez, J. M. (2019). The influence of corporate social responsibility on investment efficiency and innovation. Journal of Business Finance and Accounting, 46(3-4), 494-537.

Deng, X., Kang, J. koo, \& Low, B. S. (2013). Corporate social responsibility and stakeholder value maximization: Evidence from mergers. Journal of Financial Economics, 110(1), 87-109.

Deswanto, R. B., \& Siregar, S. V. (2018). The associations between environmental disclosures with financial performance, environmental performance, and firm value. Social Responsibility Journal, 14(1), 180-193.

Dian, F., \& Lidyah, R. (2016). Pengaruh Corporate Social Responsibility, Kepemilikan Manajerial Dan Kepemilikan Institusi Terhadap Nilai Perusahaan Tambang Batu Bara Yang Terdaftar Di BEI. Akuntansi, 4(2), 1-10.

Fajriana, A., \& Priantinah, D. (2016). Pengaruh Corporate Social Responsibility, Keputusan Investasi, dan Struktur Modal Terhadap Nilai Perusahaan. Nominal, Barometer Riset Akuntansi Dan Manajemen, 5(2), 16-28.

Gallego-Álvarez, I., Prado-Lorenzo, J. M., \& García-Sánchez, I. M. (2011). Corporate social responsibility and innovation: A resource-based theory. Management Decision, 49(10), 1709-1727.

García Lara, J. M., García Osma, B., \& Penalva, F. (2016). Accounting conservatism and firm investment efficiency. Journal of Accounting and Economics, 61(1), 221-238.

Hafez, H. (2016). Corporate social responsibility and firm value: an empirical study of an emerging economy. Journal of Governance and Regulation, 5(4), 40-53.

Handayani, R., Wahyudi, S., \& Suharnomo, S. (2017). The effects of corporate social 
responsibility on manufacturing industry performance: The mediating role of social collaboration and green innovation. Business: Theory and Practice, 18, 152159.

Harjoto, M., \& Laksmana, I. (2018). The Impact of Corporate Social Responsibility on Risk Taking and Firm Value. Journal of Business Ethics, 151, 353-373.

Hung, M., Shi, J., \& Wang, Y. (2013). The Effect of Mandatory CSR Disclosure on Information Asymmetry: Evidence from a Quasi-Natural Experiment in China. Retrieved October 4, 2019, from http://dx.doi.org/10.2139/ssrn.2206877.

Khanghah, V. T., \& Zeynali, M. (2017). Investigating the Effect of Corporate Social Responsibility on the Investment Efficiency and Innovation. Journal of Health Accounting, 5(2), 1-27.

Kholida, N., \& Susilo, D. E. (2019). Pengaruh Corporate Social Responsibility Terhadap Nilai Perusahaan Dengan Profitabilitas Sebagai Variabel Moderasi (Studi Empiris Pada Perusahaan Sektor Pertambangan Batubara Yang Terdaftar di Bursa Efek Indonesia Periode Tahun 2017-2018). Seminar Nasional Ekonomi \& Bisnis Dewanatara, 1 (79-88). STIE PGRI Dewantara Jombang.

Klewitz, J., \& Hansen, E. G. (2014). Sustainability-oriented innovation of SMEs: A systematic review. In Journal of Cleaner Production, 65(15), 57-75.

Kusumah, I. (2018). Pengaruh Profitabilitas, Ukuran Perusahaan, dan Leverage Terhadap Nilai Perusahaan (Suatu Studi pada Perusahaan Pertambangan Sub Sektor Batu Bara yang Terdaftar di Bursa Efek Indonesia Periode 2013-2017). Universitas Pasundan Bandung.

Li, Y., Gong, M., Zhang, X. Y., \& Koh, L. (2018). The impact of environmental, social, and governance disclosure on firm value: The role of CEO power. British Accounting Review, 50(1), 60-75.

MacGregor, S. P., \& Fontrodona, J. (2011). Exploring the Fit between CSR and Innovation. Retrieved October 2, 2019. https:/ / doi.org/10.2139/ssrn.1269334.

Marin, L., Martín, P. J., \& Rubio, A. (2017). Doing Good and Different! The Mediation Effect of Innovation and Investment on the Influence of CSR on Competitiveness. Corporate Social Responsibility and Environmental Management, 24(2), 159-171.

Martono, N. (2014). Metode Penelitian Kuantitatif Analisis Isi dan Analisis Data Sekunder. Jakarta: Rajawali Press.

Meilinda Murnita, P. E., \& Dwiana Putra, I. M. P. (2018). Pengaruh Corporate Social Responsibility terhadap Nilai Perusahaan dengan Profitabilitas dan Leverage Sebagai Variabel Pemoderasi. E-Jurnal Akuntansi Universitas Udayana, 23(2), 1470-1494.

Mishra, D. R. (2017). Post-innovation CSR Performance and Firm Value. Journal of Business Ethics, 140, 285-306.

Muqodim, M., \& Susilo, J. (2013). Triple bottom line reporting dalam pelaporan tahunan perusahaan go public di indonesia. Jurnal Akuntansi \& Auditing Indonesia, 17(1), 31-42.

Nur, F., Saraswati, E., \& Andayani, W. (2019). Determinan Pengungkapan Tanggung Jawab Sosial Perusahaan dan Nilai Perusahaan: Kasus Indonesia. Jurnal Dinamika Akuntansi Dan Bisnis, 6(2), 213-228.

Nur, M., \& Priantinah, D. (2012). Analisis Faktor-Faktor Yang Mempengaruhi Pengungkapan Corporate Social Responsibility Di Indonesia (Studi Empiris Pada Perusahaan Berkategori High Profile Yang Listing Di Bursa Efek Indonesia). Nominal, Barometer Riset Akuntansi Dan Manajemen, 1(2), 22-34.

Orbaningsih, D., Subroto, B., Subekti, I., \& Saraswati, E. (2017). Corporate Social 
Responsibility Disclosure, Firm Value, and Product Market Competition (Evidence from Indonesia). International Journal of Applied Business and Economic Research, 15(21), 471-482.

Prihadyanti, D., \& Laksani, C. S. (2015). R \& D dan Inovasi di Perusahaan Sektor Manufaktur Indonesia. Jurnal Manajemen Teknologi, 14(2), 187-198.

Pristianingrum, N. (2017). Pengaruh Ukuran, Profitabilitas, Dan Pengungkapan CSR Terhadap Nilai Perusahaan Manufaktur Yang Terdaftar Di Bursa Efek Indonesia. Prosiding Seminar Nasional Dan Call For Paper Ekonomi Dan Bisnis (SNAPEREBIS 2017), 353-364. Universitas Jember.

Rexhepi, G., Kurtishi, S., \& Bexheti, G. (2013). Corporate Social Responsibility (CSR) and Innovation-The Drivers of Business Growth? Procedia - Social and Behavioral Sciences, 75, 532-541.

Rustiarini, N. I. W. (2010). Pengaruh Corporate Governance Pada Hubungan CSR dan Nilai Perusahaan. Simposium Nasional Akuntansi XIII. AKPM_12.

Samet, M., \& Jarboui, A. (2017). How does corporate social responsibility contribute to investment efficiency? Journal of Multinational Financial Management, 40, 33-46.

Sheikh, S. (2018). Corporate social responsibility, product market competition, and firm value. Journal of Economics and Business, 98, 40-55.

Siswanti, I., Sukoharsono, E. G., \& Prowanta, E. (2015). The Impact of Macro Economics on Firm Values and Financial Performance as an Intervening Variable: An Empirical Study of LQ45 Banking Industries in Indonesia. Global Journal of Business and Social Science Review Journal, 3(1), 88-94.

Stacia, E., \& Juniarti. (2015). Pengaruh Pengungkapan Corporate Social Responsibility terhadap Nilai Perusahaan di Sektor Pertambangan. Business Accounting Review, 3(2), 81-90.

Sukoharsono, E. G. (2019). Sustaining a sustainability report by modifying triple bottom line to pentacle bottom line: an imaginary research dialogue. The International Journal of Accounting and Business Society, 27(1), 119-127.

Weng, H. H. R., Chen, J. S., \& Chen, P. C. (2015). Effects of green innovation on environmental and corporate performance: A stakeholder perspective. Sustainability (Switzerland), 7(5), 4997-5026.

Willim, A. P. (2015). Price Book Value \& Tobin's Q: Which One is Better for Measure Corporate Governance? European Journal of Business and Management, 7(27), 74-79.

Zhong, M., \& Gao, L. (2017). Does corporate social responsibility disclosure improve firm investment efficiency? Evidence from China. Review of Accounting and Finance, 16(3), 348-365. 